\title{
The effect of functional rice analogue diet from mocaf, corn, pigeon pea and seaweed on rats model of type 2 diabetes
}

\author{
${ }^{1,2}$ Firdausia, R.S., ${ }^{2, *}$ Rumiyati, ${ }^{2}$ Nugroho, A.E., ${ }^{3}$ Purwestri, Y.A. and ${ }^{4}$ Pranoto, Y. \\ ${ }^{1}$ Pharmacy Department, Faculty of Health, Universitas Jenderal Achmad Yani, Yogyakarta, Indonesia, \\ 55294 \\ ${ }^{2}$ Faculty of Pharmacy, Universitas Gadjah Mada, Sekip Utara, Bulaksumur, Yogyakarta, Indonesia, 53281 \\ ${ }^{3}$ Faculty of Biology, Universitas Gadjah Mada, Sekip Utara, Bulaksumur, Yogyakarta, Indonesia, 53281 \\ ${ }^{4}$ Department of Food and Agricultural Product Technology, Faculty of Agricultural Technology, \\ Universitas Gadjah Mada, Bulaksumur, Yogyakarta, 55281
}

\begin{abstract}
Article history:
Received: 22 November 2020

Received in revised form: 24

January 2021

Accepted: 2 April 2021

Available Online: 8 August 2021
\end{abstract}

\section{Keywords:}

Diabetes mellitus type 2,

Rice analogue,

Functional food,

Nutraceutical,

Diet

DOI:

https://doi.org/10.26656/fr.2017.5(4).682

\begin{abstract}
Rice analogue (RA) consisting of mocaf, corn, pigeon pea and seaweed from East Lombok, Indonesia was formulated into a low glycaemic index (GI) alternative food. The effect of this RA to control diabetes mellitus (DM) on blood glucose, insulin serum and histology of the pancreas was assayed by in vivo experiment using male and female rats aged 10 weeks that had been induced by streptozotocin (STZ) $90 \mathrm{mg} / \mathrm{kg}$ body weight 2 days after birth. The treatment was given for 14 days and compared with Broiler-1 (BR-1) feed. The GI test showed that RA has a low GI (47.36), while BR-1 has a moderate GI (66.35). The blood glucose of the RA group was significantly decreased $(p<0.05)$, while insulin serum was increased in comparison to this of BR-1. Histological observation showed an improvement in the pancreas of diabetic rats after treatment with RA in comparison to this of BR-1. The immunohistochemistry (IHC) assay showed an increase in insulin expression in RA-treated diabetic rats. This study concluded that RA has a low GI. The products were able to increase serum insulin, improve morphological Langerhans and insulin expression on rats model of type $2 \mathrm{DM}$.
\end{abstract}

\section{Introduction}

Diabetes Mellitus (DM) type 2 one of the degenerative diseases that contribute to the most causes of death in Indonesia. Based on data from the Diabetes Association, Indonesia is one of the Asian countries ranked among the countries with the highest number of patients with diabetes worldwide (Saeedi et al., 2019). The American Diabetes Association has identified selfdietary management as the key to maintaining blood sugar levels and preventing diabetic complications (William and Cefalu, 2017). In self-dietary management, carbohydrates and dietary fibres are components of particular concern in the management of diabetic patients (Steyn et al., 2004). Carbohydrate intake has a direct effect on postprandial glucose levels in people with diabetes. Low glycemic index (GI) foods relate to the rate at which carbohydrates are absorbed from the gut. Low-GI foods are characterized by the slow rate of carbohydrate absorption (slow-release carbohydrate) resulting in a lower rise in blood glucose levels. Many factors may influence the digestion of carbohydrates in the small intestine, including the amount of fibre (Julia and Jenkins, 2007). In addition, the presence of dietary antioxidants can affect oxidative stress and health status. Based on the research by Rani et al. (2019) and Sekhon et al. (2017), pigeon pea seeds are a potential source of antioxidants of natural origin due to high total phenols compounds. The radical scavenging ability of pigeon pea antioxidant compounds may inhibit oxidative damage caused by STZ induction, thereby insulin secretion is enhanced thus lowering glucose levels.

Rice analogue is a functional food in the form of grains of rice made of non-rice materials (Budijanto and Yuliana, 2015; Noviasari et al., 2015). Rice analogue production is a means to produce a local source of raw materials into new forms of food with more benefits, such as a low GI and a source of fibre (Budijanto and Yuliana, 2015). Several rice analogues formulations have been developed with a range of raw materials such as white corn, sorghum with the addition of soy flour by Noviasari et al. (2015); cornflour, sago flour, soy flour and rice bran by Budijanto et al. (2016); fresh cassava, 
sago starch, coconut pulp and rice bran by Budijanto et al. (2016); rice analogue enriched with phytosterol esters by Sadek (2017); raw menir (byproducts of the milling process of paddy) with the addition of black tea extract by Yahya (2013); cassava flour enriched with tuna protein by Franciska et al. (2015); and cassava flour, peas and hanjeli flour (Coix lacryma-jobi L.) by Sumardiono et al. (2014). Rice analogue formulated by Sadek (2017) has been proven to inhibit the development of colon cancer in Balb/c mice strain through inflammatory suppression and induction of apoptosis. In addition, analogue rice made from fresh cassava, sago starch, coconut pulp and rice bran formulated by Budijanto et al. (2016) showed hypocholesterolemic effects by reducing total cholesterol, LDL levels and increasing HDL levels compared to the control rat group. It has been shown that processing local sources of raw materials into new forms of food like analogue rice can increase health benefits and the sale value of the raw material ingredients.

The rice analogue used in this study consists of mocaf $(71 \%)$, corn $(21 \%)$, pigeon pea $(7 \%)$ and seaweed (1\%) collected from East Lombok, West Nusa Tenggara, Indonesia. Based on a literature search, results show that this compound has never been formulated by other researchers. Based on these components such as mocaf and corn that has a low GI, supported by fibre from seaweed and dietary-antioxidant components of pigeon pea are expected to control DM type 2 by providing an alternative food substitute for rice which is known to have high sugar content. This study was conducted to investigate the glycemic index value and effect of rice analogue consisting of mocaf, corn, pigeon pea and seaweed as a diet food in diabetic rats, evaluated using the parameter of blood glucose level, serum insulin level, Langerhans morphology and insulin expression in the pancreas of rats model DM type 2.

\section{Materials and methods}

\subsection{Raw materials}

Raw materials for the rice analogue included cassava roots (Manihot esculenta Crantz) as modified cassava flour (mocaf), corn (Zea mays L.), pigeon pea (Cajanus cajan L. Millsp) and dried seaweed (Euchema cottonii); Broiler-1 (BR-1) feed by PT Japfa Comfeed, Indonesia.

\subsection{Animal ethics}

This study was approved by the Ethical Committee of Laboratorium Penelitian dan Pengujian Terpadu Universitas Gadjah Mada, Indonesia with the approval number 00145/04/LPPT/XII/2017.

\subsection{Analytical method}

\subsubsection{Preparation of rice analogue}

The raw materials (mocaf, corn, pigeon pea and seaweed) were weighted based on a predetermined percentage, then mixed evenly. The mixture was added by $30 \%$ millilitres water of total mixture and $0.5 \%$ binder (CMC Na (Sodium Carboxymethyl cellulose)) of the total mixture then mixed thoroughly. The dough was steamed for 15 mins to make a pregelatinized dough so that the dough can be moulded into rice in the extrusion process. The extrusion process was done with an EXTD-01SC single screw extruder machine (Serpong, Tangerang), three times. The rice grains were then dried at a temperature of $50^{\circ} \mathrm{C}$ in the drying cabinet/oven for 12 hrs to achieve a water content of less than $10 \%$. These methods adapted from Budijanto and Yuliana (2015) with some modifications.

\subsubsection{Glycemic index value measurement}

The glycemic index measurement was adapted Sari et al. (2013) method with some modifications. Glycemic index measurement of rice analogue was compared to BR-1 feed was performed by in vivo test using 20 male Wistar rats ( 2 months old). They were divided into 4 groups of treatments consisting of $\mathrm{CMC} \mathrm{Na} 0.1 \%$ group, glucose $2.5 \mathrm{~g} / \mathrm{kg} \mathrm{BW}$ (bodyweight) group, rice analogue group and BR-1 feed group. Rats were fasted for 8 hours, then given each sample orally once. Blood sampling was taken at 0,30 th, 60th and 120th minutes after sampling, then measured by using a Glucose GOD-PAP kit. The glycemic index was determined by calculating the ratio between the Area Under Curve (AUC) samples compared to AUC glucose as follows:

$$
\text { GI value }=\frac{\text { AUC sample }}{\text { AUC glucose }} \times 100 \%
$$

\subsubsection{Antidiabetic assay}

Antidiabetic assay in this study was performed according to a previous study (Nugroho et al., 2014) using n-STZ (neonatal streptozotocin-induced) model with 20 male and 20 female Wistar rats. The rats were divided into 4 groups. Group 1: normal rats were given BR-1 feed, group 2: diabetic rats were given BR-1 feed, group 3: normal rats were given rice analogue, group 4: diabetic rats were given rice analogue. Diabetic groups were injected with streptozotocin (STZ) (Nacalai, Japan) dissolved in $0.1 \mathrm{M}$ sodium citrate buffer $\mathrm{pH} 4.5$ at a dose of $90 \mathrm{mg} / \mathrm{kg} \mathrm{BW}$ intraperitoneally at the age of 2 days after birth.

Rice analogue and BR-1 treatments were given at 10 weeks old to normal and hyperglycaemia rats. Treatments were applied for 14 days by giving food up to $10 \%$ of body weight (gram) and water $100 \mathrm{~mL}$ every 
day. Measurements of the remaining food and water were carried out every day while weighing each rat was carried out every week.

Blood sampling of the rats, via the retro-orbital plexus was taken on day 0,7 and 14 after treatments. Blood samples were processed for blood glucose determination by the spectrophotometric method (Syamsul et al., 2011), while the determination of serum insulin levels was processed by the ELISA method (Wuhan Fine Biotech, 2016). After the 14th day, the rats were sacrificed and their pancreas organs were taken. Pancreatic organs were prepared then stained using Hematoxylin Eosin (HE) to analyze the morphology of Langerhans and immunohistochemical (IHC) test to determine the expression of insulin in the pancreas (Meyerholz and Beck, 2018).

\subsection{Data analysis}

Rat blood glucose and insulin levels were analyzed by one-way analysis of variance (ANOVA) and the results are reported as mean $\pm \mathrm{SD}$ (Standard Deviation). The significance of the differences was defined as $\mathrm{P}<0.05$. Morphological data of the Langerhans were analyzed qualitatively and semi-quantitatively based on conditions and diameter of the Langerhans in the treatment group with negative control. Insulin expression in the pancreas was analysed semiquantitatively based on the intensity of the colour formed. Whereby the intensity of the colour formed is proportional to the expression of insulin and scoring was done using the ordinal method then analyzed with non-parametric analysis Kruskall-
Wallis and Mann-Whitney (Meyerholz and Beck, 2018).

\section{Results}

The rice analogue in this study was made from 4 raw materials including mocaf $(71 \%)$, corn $(21 \%)$, pigeon pea $(7 \%)$ and seaweed $(1 \%)$. Based on research reported by Sani (2018), this rice analogue contains $0.93(\% \mathrm{db})$ of ash; $5.08(\% \mathrm{db})$ of protein; $0.24(\% \mathrm{db})$ of fat; 97.00 $(\% \mathrm{db})$ of carbohydrates and $9.3(\% \mathrm{wb})$ of water. In this study, this rice analogue was analyzed for its glycemic index (GI) value and antidiabetic activity compared to BR-1 feed.

\subsection{GI value measurement}

The GI values of the rice analogue and BR-1 feed based on the AUC comparison are presented in Table 1. The calculation results showed that the BR-1 feed has a GI value of 66.35 , while the rice analogue has a value of 47.35. Based on the GI classification, BR-1 feed has a moderate GI (50-70), while the rice analogue has a low GI (<55) (Steyn et al., 2004).

\subsection{Antidiabetic assay}

\subsubsection{Intake level and body weight}

Observation results of food intake levels of male and female rats in each group are presented in Table 2 and Table 3. Average food and water intakes in male rats were significantly higher than that of female rats $(p<0.05)$. As an example, the average food intake of normal male rats with BR-1 feed was $14.51 \mathrm{~g}$ while in the female group were $11.41 \mathrm{~g}$. This effect may be due to

Table 1. The glycemic index value of rice analogue and BR-1 feed compared to glucose standard

\begin{tabular}{|c|c|c|c|c|c|c|}
\hline \multirow{2}{*}{ Sample } & \multicolumn{4}{|c|}{ Blood glucose level } & \multirow{2}{*}{ AUC } & \multirow{2}{*}{ GI } \\
\hline & $0 \mathrm{~min}$ & 30 mins & 60 mins & 120 mins & & \\
\hline Rice analogue & $9.16 \pm 4.07$ & $12.23 \pm 1.64$ & $14.30 \pm 5.52$ & $9.48 \pm 2.89$ & 1432.2 & 47.36 \\
\hline BR-1 feed & $11.71 \pm 2.71$ & $17.58 \pm 8.00$ & $19.88 \pm 8.39$ & $13.63 \pm 2.68$ & 2006.2 & 66.35 \\
\hline
\end{tabular}

Table 2. Average daily food intake of male and female rats day 0 until day 14

\begin{tabular}{lccc}
\hline \multirow{2}{*}{ Group } & \multicolumn{3}{c}{ Average (g) } \\
\cline { 2 - 4 } & Day 0 & Day 7 & Day 14 \\
\hline Male rats & & & \\
\hline Normal with BR-1 feed & $15.21 \pm 0.79$ & $14.00 \pm 0.41$ & $14.33 \pm 0.67$ \\
DM with BR-1 feed & $15.00 \pm 0.0$ & $14.24 \pm 0.38$ & $17.87 \pm 0.45^{\mathrm{a}, \mathrm{b}}$ \\
Normal with rice analogue & $7.40 \pm 0.24$ & $7.53 \pm 0.97$ & $6.57 \pm 0.68$ \\
DM with rice analogue & $8.00 \pm 0.41$ & $9.90 \pm 0.78$ & $7.47 \pm 0.78$ \\
\hline Female rats & & & \\
\hline Normal with BR-1 feed & $13.00 \pm 0.00$ & $10.65 \pm 0.30^{\mathrm{c}}$ & $10.57 \pm 1.32$ \\
DM with BR-1 feed & $13.40 \pm 0.24$ & $10.05 \pm 0.15^{\mathrm{c}}$ & $11.40 \pm 0.40^{\mathrm{a}, \mathrm{b}}$ \\
Normal with rice analogue & $7.00 \pm 0.45$ & $6.96 \pm 0.027$ & $7.25 \pm 0.72$ \\
DM with rice analogue & $8.83 \pm 0.60$ & $7.84 \pm 0.46$ & $8.40 \pm 0.53$ \\
\hline
\end{tabular}

Values are displayed in average \pm SEM, ${ }^{a}(p<0.05)$ between day 14 and day 0 in one group, ${ }^{b}(p<0.05)$ between day 14 and day 7 in one group, ${ }^{c}(\mathrm{p}<0.05)$ between day 7 and day 0 in one group. 
Table 3 . Average daily water intake male and female rats on day 0 until day 14

\begin{tabular}{lccc}
\hline \multirow{2}{*}{\multicolumn{1}{c}{ Group }} & \multicolumn{3}{c}{ Average (g) } \\
\cline { 2 - 4 } & Day 0 & Day 7 & Day 14 \\
\hline Male rats & \multicolumn{3}{c}{} \\
\hline Normal with BR-1 feed & $28.79 \pm 2.77$ & $27.81 \pm 1.27$ & $26.67 \pm 2.03$ \\
DM with BR-1 feed & $30.03 \pm 1.26$ & $30.04 \pm 2.69$ & $35.76 \pm 2.76$ \\
Normal with rice analogue & $16.01 \pm 1.57$ & $14.01 \pm 2.47$ & $14.03 \pm 2.23$ \\
DM with rice analogue & $18.37 \pm 0.87$ & $15.80 \pm 1.56$ & $19.11 \pm 2.21$ \\
\hline Female rats & \multicolumn{3}{|c}{} \\
\hline Normal with BR-1 feed & $26.95 \pm 2.88$ & $27.48 \pm 1.29$ & $21.49 \pm 1.63$ \\
DM with BR-1 feed & $26.43 \pm 2.80$ & $23.09 \pm 3.66$ & $23.00 \pm 2.74$ \\
Normal with rice analogue & $19.09 \pm 2.57$ & $12.37 \pm 0.82$ & $18.27 \pm 1.75^{\mathrm{b}}$ \\
DM with rice analogue & $28.19 \pm 3.94$ & $25.90 \pm 3.94$ & $17.53 \pm 2.03^{\mathrm{a}}$ \\
\hline
\end{tabular}

Values are displayed in average \pm SEM, ${ }^{a}(p<0.05)$ between day 14 and day 0 in one group, ${ }^{b}(p<0.05)$ between day 14 and day 7 in one group.

the influence of hormones on the level of appetite in female rats as was previously observed by Asarian and Geary (2013). The average rice analogue intake showed a value reaching half the average of BR-1 feed. This could be a concern for further observation regarding the intake level of rice analogue which is below the normal intake rate of $10 \%$ of the rat's body weight. The average food and water intake in the diabetes group were higher than the normal group but did not show a significant difference $(p>0.05)$. This is consistent with research conducted by Tian and Wei (2010), where there was a correlation between diabetes induction by STZ and the food and water intake of rats. STZ-induced rats had higher fasting glucose levels than normal, higher food and water intake compared to normal, but weight loss occurred. This can be seen in Table 4, the body weight of male and female DM rats in the rice analogue group decreased on day 14 after treatment although not significantly $(p>0.05)$. In the normal group of rice analogue, both male and female rats did not significantly decrease body weight after rice analogue treatment of 14 days $(p>0.05)$, while in the normal group of BR-1 feed male and female rats had an insignificant change in body weight after treatment for 14 days $(\mathrm{p}>0.05)$.

\subsection{Effect on blood glucose level}

Treatments were given at the 10th week after STZ induction, wherein the 10th week the rats had hyperglycemia. The results of treatment for 14 days showed a significant decrease in blood glucose levels in the rice analogue groups shown in Table 5, Figure 1A and B. Based on Figure 1, on day 0 shortly before being given treatment, between the normal group and malefemale DM group in each treatment, there were significant differences which indicate that hyperglycemia had occurred $(\mathrm{p}<0.05)$

Treatment was given to each group for 14 days. In the normal male group given rice analogue for 14 days, there was a significant change $(p<0.05)$. This may be a concern and further monitoring is needed regarding the use of the rice analogue in the long term whether it has a hypoglycemic effect or not. In the male DM group, BR-1 feeding for 14 days did not show a significant decrease

Table 4. Average body weight of male and female rats on day 0 until day 14

\begin{tabular}{lccc}
\hline \multirow{2}{*}{ Group } & \multicolumn{3}{c}{ Average (g) } \\
\cline { 2 - 4 } & Day 0 & Day 7 & Day 14 \\
\hline Male rats & $198 \pm 13.73$ & $213.68 \pm 18.15$ & $219.18 \pm 18.51$ \\
\hline Normal with BR-1 feed & $218.16 \pm 3.80$ & $235.84 \pm 6.87$ & $271.20 \pm 9.60^{\mathrm{a}}$ \\
DM with BR-1 feed & $121.20 \pm 6.39$ & $110.63 \pm 7.15$ & $109.98 \pm 7.27$ \\
Normal with rice analogue & $138.38 \pm 5.75$ & $128.03 \pm 4.78$ & $123.70 \pm 5.21$ \\
DM with rice analogue & $171.28 \pm 6.72$ & $175.34 \pm 6.56$ & $181.75 \pm 6.81$ \\
\hline Female rats & $153.44 \pm 11.32$ & $162.12 \pm 11.64$ & $178.40 \pm 12.06$ \\
Normal with BR-1 feed & $126.33 \pm 8.08$ & $117.22 \pm 5.35$ & $111.60 \pm 6.09$ \\
DM with BR-1 feed & $150.65 \pm 2.17$ & $148.45 \pm 6.11$ & $146.73 \pm 5.20$ \\
Normal with rice analogue &
\end{tabular}

Values are displayed in average $\pm \operatorname{SEM},{ }^{a}(p<0.05)$ between day 14 and day 0 in one group 
Table 5. Blood glucose level (mg/dL) at day 0, 7 and 14 after treatment

\begin{tabular}{lccc}
\hline \multirow{2}{*}{ Group } & \multicolumn{3}{c}{ Average $(\mathrm{g})$} \\
\cline { 2 - 4 } & Day 0 & Day 7 & Day 14 \\
\hline Male rats & $82.88 \pm 6.41$ & $88.12 \pm 5.52$ & $85.63 \pm 6.46$ \\
\hline Normal with BR-1 feed & $131.83 \pm 9.74^{\mathrm{c}}$ & $119.20 \pm 13.80$ & $124.20 \pm 7.13$ \\
DM with BR-1 feed & $78.74 \pm 5.07$ & $67.60 \pm 6.96$ & $56.50 \pm 3.30^{\mathrm{a}}$ \\
Normal with rice analogue & $122.72 \pm 6.37^{\mathrm{d}}$ & $65.90 \pm 10.79^{\mathrm{b}}$ & $60.79 \pm 10.25^{\mathrm{a}}$ \\
DM with rice analogue & & & \\
\hline Female rats & $84.36 \pm 7.47$ & $80.50 \pm 4.23$ & $81.43 \pm 1.62$ \\
\hline Normal with BR-1 feed & $133.06 \pm 9.75^{\mathrm{c}}$ & $114.10 \pm 5.82$ & $112.88 \pm 6.55$ \\
DM with BR-1 feed & $90.13 \pm 5.16$ & $86.68 \pm 2.79$ & $78.13 \pm 4.11$ \\
Normal with rice analogue & $139.50 \pm 15.49^{\mathrm{d}}$ & $101.86 \pm 7.70$ & $88.98 \pm 3.34^{\mathrm{b}}$ \\
\hline DM with rice analogue &
\end{tabular}

Values are displayed in average \pm SEM. ${ }^{a}(p<0.05)$ between day 14 and day 0 in one group, ${ }^{b}(p<0.05)$ between day 7 and day 0 in one group, ${ }^{c}(p<0.05)$ between normal and DM BR-1 feed group at day $0,{ }^{d}(p<0.05)$ between normal and DM rice analogue group at day 0 .
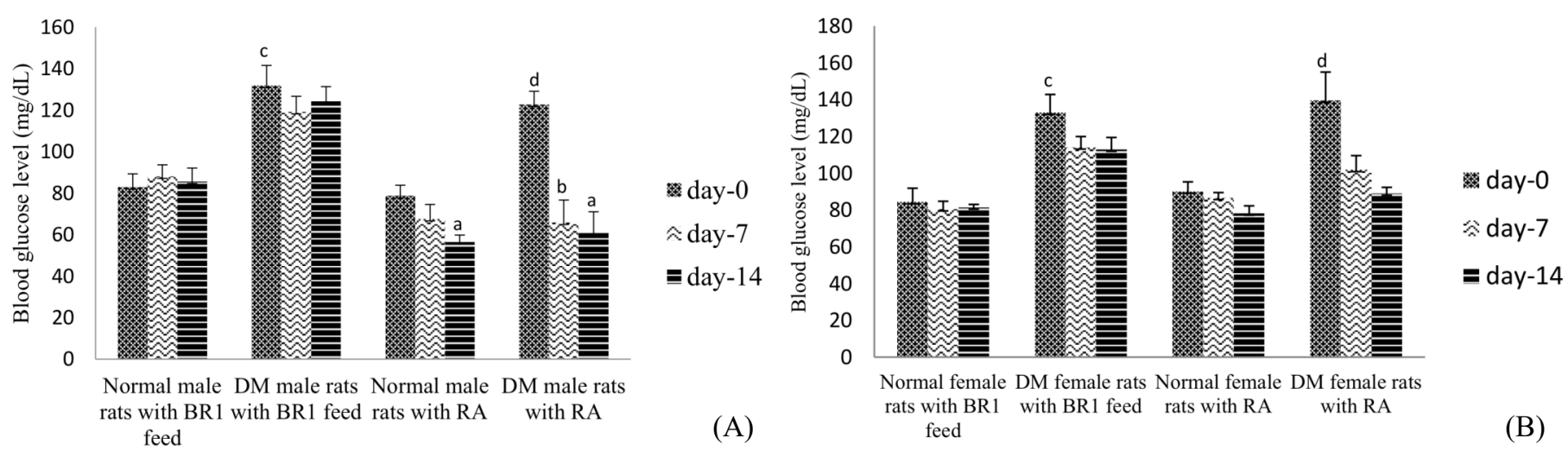

Figure 1. Histogram of average blood glucose levels on day 0 until day 14 after treatment in male rats (A) and female rats (B). ${ }^{a}$ $(\mathrm{p}<0.05)$ between day 14 and day 0 in one group, ${ }^{b}(p<0.05)$ between day 7 and day 0 in one group, ${ }^{c}(p<0.05)$ between normal rats with BR-1 and DM rats with BR-1 day $0,{ }^{d}(p<0.05)$ between normal rats with rice analogue and DM rats with rice analogue day 0 .

in blood glucose levels $(\mathrm{p}>0.05)$, which was different from the case of the DM male group treated with rice analogue. The rice analogue DM male group showed a significant change in blood glucose levels on day 7 and day 14 after administration $(\mathrm{p}<0.05)$. When comparing glucose levels in the DM group rice analogue on the 7th and 14th day after administration, there were no significant changes $(p>0.05)$. This is supported by statistical results which show no significant difference ( $>0.05)$ in the normal group of rice analogue and DM rice analogue on day 14 after treatment. Based on these results it can be seen that analogue rice is able to maintain the stability of blood glucose levels close to normal after 14 days of treatment. The same thing happened in the female group. Based on Figure 1B, there was no significant difference in the DM group after BR1 treatment for 14 days $(p>0.05)$, whereas in the DM group given rice analogue there were significant differences in blood glucose levels after 14 days of administration $(\mathrm{p}<0.05)$.

\subsection{Effect on serum insulin}

The results in Figure 2 showed that insulin levels in the group of rats induced by STZ were lower than normal rats $(p<0.05)$. But after the treatment of rice analogue for 14 days, male rats showed an increase in serum insulin levels which proved no significant differences in the group on normal male rats and male DM rats on day $14(p>0.05)$. Whereas in the male group given BR-1 there was no difference in serum insulin levels. In the female group, the administration of BR-1 feed for 14 days showed a significant difference to normal BR-1 females on the 14 th day $(\mathrm{p}<0.05)$. This showed no improvement in serum insulin levels by following BR-1 feed. While the treatment of rice analogue for 14 days in STZ-induced female rats showed a significant change in serum insulin level on day 14 compared to day $0 \quad(p<0.05)$. This showed an improvement in serum insulin levels by giving rice analogue for 14 days in female DM rats.

\subsection{Morphology of pancreas}

Hematoxylin-Eosin (HE) staining of the pancreas was carried out to determine the morphological changes 


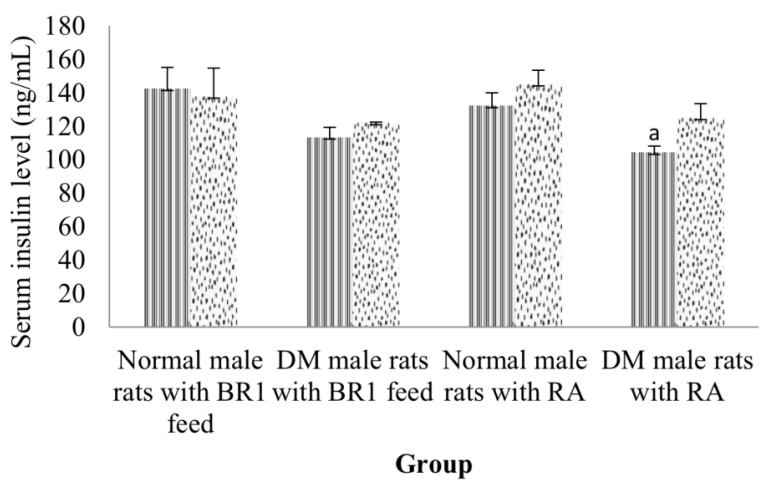

$$
\begin{aligned}
& \text { IIII day- } 0 \\
& \text { day-14 }
\end{aligned}
$$

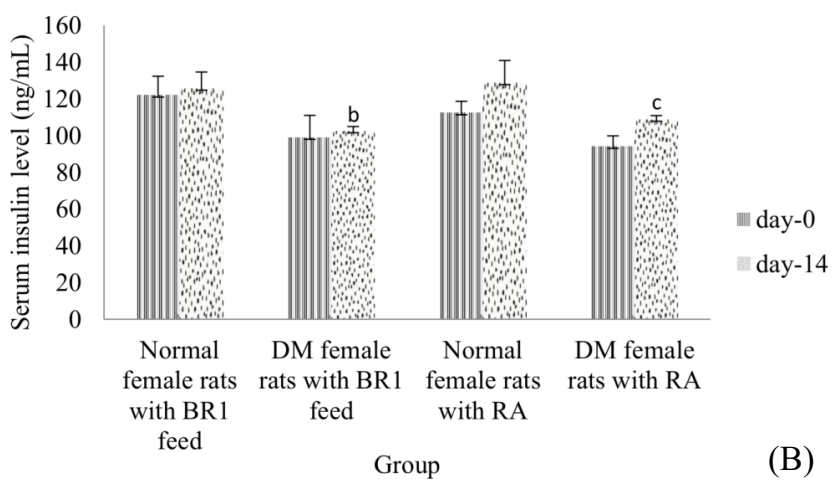

Figure 2. Histogram of serum insulin levels on day 0 and day 14 after treatment in male rats (A) and female rats (B). ${ }^{a} \mathrm{p}<0.05$ between normal male rats with rice analogue day 0 and DM male rats with rice analogue, ${ }^{b} p<0.05$ between day 14 of normal female rats with BR-1 feed and DM female rats with BR-1 feed, ${ }^{c} p<0.05$ between DM female rats with rice analogue day 14 and day 0 in one group.

in the islet of Langerhans. Morphology was observed by looking at the condition, shape and size of the preparation under the microscope with a 40x magnification (Figure 3). STZ induction results in damage to the islet of Langerhans which caused a decrease in the number of pancreatic beta cells and insulin expression. Damage on islet Langerhans could be observed from the differences in islet Langerhans morphology of normal male and female rats in Figure $3 \mathrm{~A}, \mathrm{C}, \mathrm{E}$ and $\mathrm{G}$ compared to the group induced by STZ in Figure $3 \mathrm{~B}$ and $\mathrm{F}$. In the normal group the cells are very rapid, small intercellular intercourse and cytoplasmic boundary are very clear, whereas in the DM group of BR-1 feed-in male rats (Figure 3B) and females (Figure 3F) there are many intercellular intercourses, cells appear to spread and rarely. Qualitatively, it can be seen in Figures 3D and $\mathrm{H}$, with the treatment of rice analogue for 14 days showed better morphological conditions indicated by rapid cells compared to DM groups given BR-1 feed-in Figures 3B and F.

\subsection{Insulin expression}

The analysis was done by observing immunoreactive insulin cell expression, indicated by the presence of a brown spot on the islet of Langerhans. Based on Figure 4 it can be seen qualitatively, that in the DM group both males and females (Figure 4B, D, F, and H) had a lower intensity brown colour in $\mathrm{b}$ cells Langerhans than the normal group. Administration of rice analogue in DM rats for 14 days showed higher insulin expression in both male rats (Figure 4D) and female rats (Figure 4H) compared with DM rats given BR-1 feed for 14 days (Figure 4B and Figure 4F) because of the immunoreactive increase that might be due to cell regeneration characterized by more concentrated brown.

Insulin expression on the pancreas was analyzed semi-quantitatively by looking at the intensity of the colour formed. The colour intensity formed is proportional to the insulin expression of each group.
Scoring intensity was done by the ordinal masking method. The colour intensity formed is categorized with ordinal numbers by scoring 3 for strong intensity, 2 for moderate intensity and 1 for low intensity (Meyerholz and Beck, 2018). The results of the scoring were compared in the form of percentage (\%) with the total scoring in one group. The total scoring results were analyzed using non-parametric analysis with KruskallWallis and Mann-Whitney to find out differences between groups. The results of observations of insulin expression on the pancreas of each group can be seen in Table 6.

Scoring results showed that the DM group induced by STZ in both male and female rats showed a lower percentage of strong intensity insulin expression compared to the normal group. Statistical results showed a significant difference in insulin expression on day 14 in the normal group compared to the DM group $(\mathrm{p}<0.05)$. It showed that the number of Langerhans cells diabetic group which secrete insulin was less than the normal group, so that cell expression immunoreactive to insulin was low. The treatment of rice analogue for 14 days in male rats did not change the insulin expression which indicated a significant difference with the normal group, whereas in female rats showed a change indicated by no significant difference with the normal group ( $>0.05$ ). This showed that treating rice analogue for 14 days giving high insulin expression to the pancreas of rats in the DM female group compared to other groups.

\section{Discussion}

The results of glycemic index testing showed that rice analogue had a low glycemic index (GI) (47.36), while BR-1 feed had a moderate GI (66.35). This is due to the high resistant starch content of rice analogue mainly derived from mocaf and corn components, so it is slowly absorbed resulting in a lower rise in blood glucose levels (Srikaeo and Sangkhiaw, 2014). 


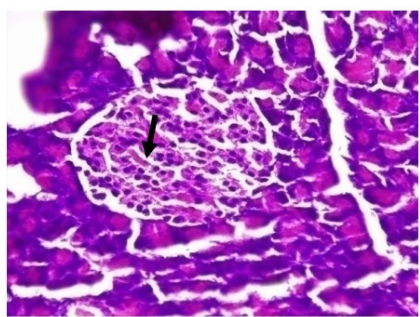

(A)

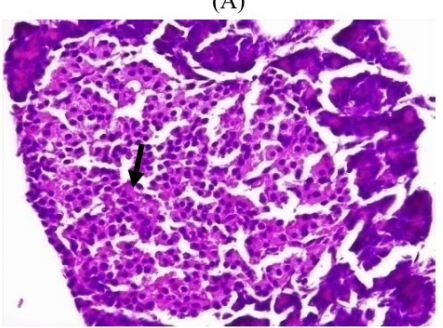

(C)

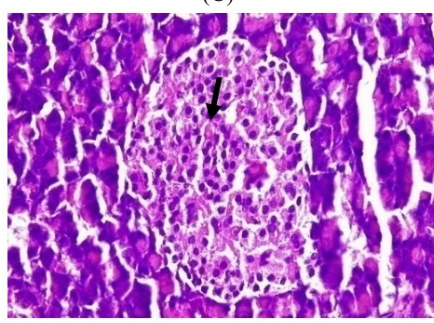

(E)

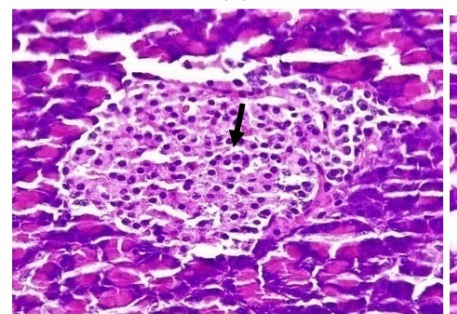

(G)

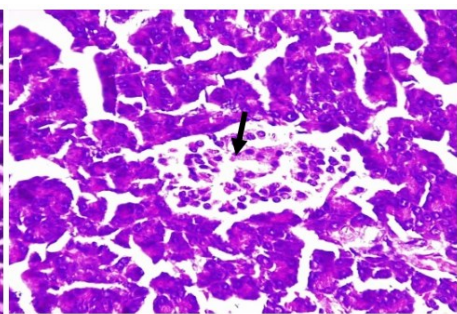

(B)

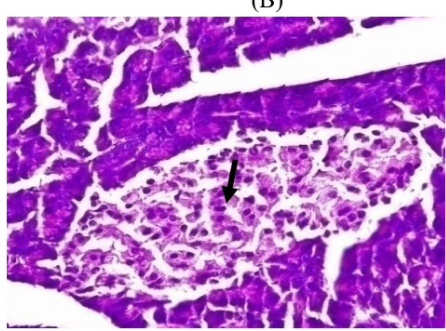

(D)

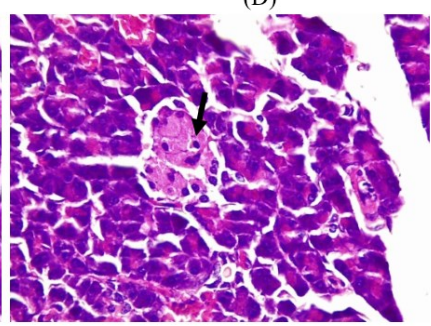

(F)

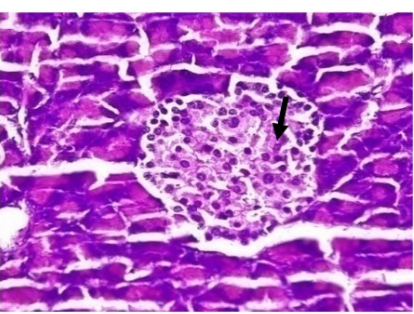

(H)

Figure 3. Histologic description of Langerhans rats by HE staining with 40x magnification in normal male rats (A) and female rats (E) with BR-1 feed, DM male rats (B) and female rats $(\mathrm{F})$ with $\mathrm{BR}-1$ feed, normal male rats $(\mathrm{C})$ and female rats $(\mathrm{G})$ with rice analogue, DM male rats $(\mathrm{F})$ and female rats $(\mathrm{H})$ with rice analogue, arrows (à) indicate changes in density between cells

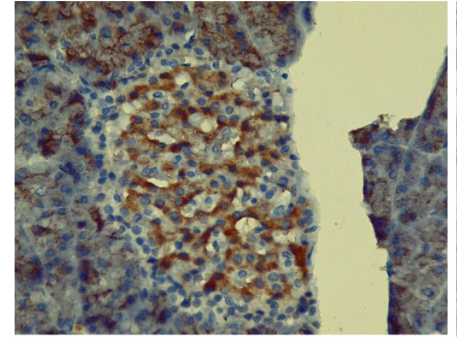

(A)

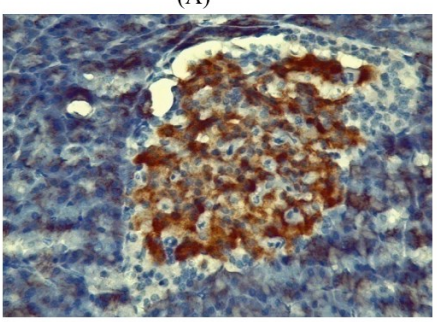

(C)

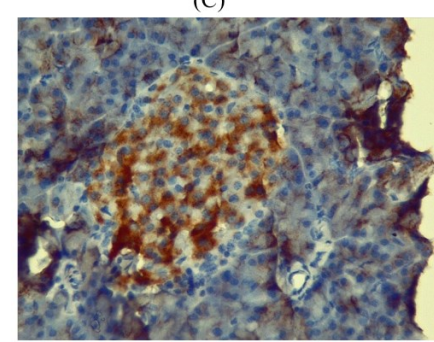

(E)

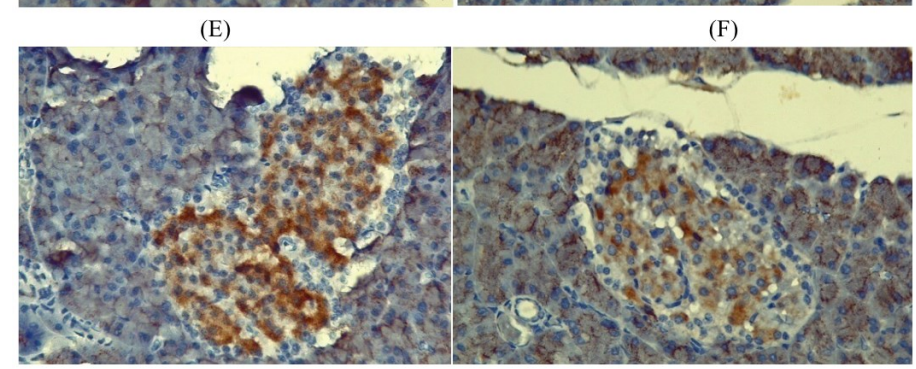

(G)

(H)

Figure 4. Description of pancreatic insulin expression by immunohistochemical method in normal male rats (A) and female rats (E) with BR-1 feed, DM male rats (B) and female rats $(F)$ with BR-1 feed, normal male rats $(C)$ and female rats (G) with rice analogue, DM male rats (D) and female rats (H) with rice analogue.

Table 6. Expression intensity scoring results (\%) with IHC method

\begin{tabular}{lccc}
\hline \multirow{2}{*}{ Group } & \multicolumn{3}{c}{ Percentage (\%) } \\
\cline { 2 - 4 } & 3 & 2 & 1 \\
\hline Male rats & 47.62 & 47.62 & 4.76 \\
\hline Normal with BR-1 feed & 38 & 60 & 2 \\
DM with BR-1 feed & 61.29 & 25.81 & 12.9 \\
Normal with rice analogue & 48 & 47 & 5 \\
DM with rice analogue & & & \\
\hline Female rats & 35.42 & 58.33 & 6.25 \\
Normal with BR-1 feed & 27.78 & 66.67 & 5.56 \\
DM with BR-1 feed & 60.96 & 35.04 & 4 \\
Normal with rice analogue & 60 & 37.5 & 2.5 \\
DM with rice analogue &
\end{tabular}

Values are displayed in descriptive data percentage of colour intensity in one group. ${ }^{\mathrm{a}}(\mathrm{p}<0.05)$ between male normal rats with BR-1 and DM rats with BR-1, ${ }^{b}(p<0.05)$ between male normal rats with rice analogue and DM rats with rice analogue, ${ }^{c}(p<0.05)$ between female normal rats with BR-1 and DM rats with BR-1, ${ }^{\mathrm{d}}(\mathrm{p}<0.05)$ between male normal rats with BR-1 and normal rats with rice analogue, ${ }^{e}(p<0.05)$ between male DM rats with BR-1 and DM rats with rice analogue, ${ }^{f}(p<0.05)$ between female normal rats with BR-1 and normal rats with rice analogue, ${ }^{\mathrm{g}}(\mathrm{p}<0.05)$ between female DM rats with BR-1 and DM rats with rice analogue 
Induction of STZ on animal models showed the occurrence of hyperglycemia at the 12th week that was shown by glucose levels 1.5 times higher than normal (Anwar et al., 2017). The success of STZ in damaging pancreatic cells could be seen from the islet of Langerhans morphology that was worse than the normal groups (Figure 3). Treatments of the rice analogue for 14 days showed a significant decrease in blood glucose levels in the rice analogue group on the 7th and 14th day in male rats, and on the 14th day in female rats. This may be due to the low GI of the rice analogue (Firdausia, 2018). In addition to GI factors, a decrease in blood glucose levels is due to the role of antioxidants derived from components contained in rice analogue, especially pigeon pea. The amount of phenolic content and antioxidant activity of pigeon pea is known to have an enzyme $(\alpha$-glucosidase and $\alpha$-amylase) inhibitory potential. $\alpha$-amylase catalyzes the breakdown of glycosidic linkages in the carbohydrate and gives away the broken products. The enzymatic degradation of the polymer constitutes the first step. Starch blockers, $(\alpha-$ amylase inhibitors) bind with the reactive sites by altering its catalytic activity, thereby causing a decrease in blood glucose level, whereas the $\alpha$-glucosidase which is released from the cells lining of the small intestine results in the cleavage of di and oligosaccharide to glucose and its assimilation in the intestine (Uchegbu and Ishiwu, 2015).

Blood glucose in the normal male group treated with rice analogue on day 14 showed a significant decrease. This result needs to be investigated further to understand whether consuming rice analogue continuously could cause hypoglycemia. This result also influenced by the amount of food and water intake. The average intake of rice analogue in male and female rats showed a significant difference $(p<0.05)$ compared to the amount of BR-1 feed intake, this may be due to BR-1 feed being a standard feed used as an animal feed containing more components that can increase hunger in rats (Witosari and Widyastuti, 2014). This can also be attributed to low GI which is owned by rice analogue, low-GI foods are known to be absorbed slowly in the body, giving a longer feeling of satiety compared to high-GI foods $(\mathrm{Hu}$ et al., 2001). But this can be a concern to further investigations which may be due to the content contained therein was foreign to the mouse compared to the food it was used to eating possibly made an unpleasant taste for rats that affect the appetite.

Food and water intake in male and female rats showed an influence on body weight. The treatment of rice analogue for 14 days showed an insignificant decrease in body weight seen with $\mathrm{p}>0.05$, whereas in the normal group BR-1 fed male and female rats had an insignificant increase in body weight after BR-1 feeding for 14 days. This can be related to the composition of nutrients in each feed. In rice analogue, the largest composition contained in it is a carbohydrate, whereas in the composition of BR-1 feed there are additional vitamins and minerals that can increase growth and appetite (Witosari and Widyastuti, 2014), resulting in an increase in body weight with BR-1 feeding.

The effect of rice analogue on STZ-induced diabetic rats can be seen with serum insulin and insulin parameters in the pancreatic organs. Insulin is the main hormone that plays a role in regulating glucose in the body. The results showed that in the DM group, insulin levels in the serum were lower than in the normal group. This may be due to a disruption of insulin secretion in DM rats that damage the $\beta$ pancreatic cells resulting in a decrease in serum insulin levels shown in Figure 2. Treatment of rice analogue for 14 days showed a significant increase in serum insulin levels in female rats compared to the DM group. However, in male rats, there was no significant difference in insulin levels when compared between day 14 and day 0 in the male group DM with rice analogue. This can be due to the effect of the hormone estrogen which can affect pancreatic $\beta$ cells (Le May et al., 2006).

The expression of insulin was observed using immunohistochemical testing on the pancreatic organs. The results obtained showed a positive correlation between blood glucose levels and serum insulin levels and insulin expression in the pancreas. In the group of male and normal females, BR-1 feed compared with the DM group male and female BR-1 feed, with the administration of treatment for 14 days did not show a significant difference in blood glucose levels $(p>0.05)$. High glucose levels made low insulin secretion and low pancreatic insulin expression compared to normal (Hu et al., 2001). In the IHC results of Figure 4, it shows moderate to a weak brown colour intensity that indicates the $\beta$ pancreatic cells in the group are less so they express insulin weakly and the secreted insulin is unable to compensate for the glucose entering so blood glucose levels remain high.

The opposite results showed in the treatment with rice analogue for 14 days showing a significant decrease in blood glucose levels. Serum insulin levels also showed a significant difference compared to day0. These results can be attributed to the expression of insulin produced at IHC, wherein the male and female groups showed brown colour with strong to moderate intensity, which showed more immunoreactive insulin against antibodies. The amount of insulin that is immunoreactive against antibodies is directly proportional to the amount of insulin secreted by pancreatic $\beta$ cells due to the 
influence of rice analogue when compared to treatment with BR-1 feed. Insulin excreted into the blood will cause a significant decrease in glucose levels. The results of observations of insulin expression at IHC can be used as evidence that although the rice analogue intake rate in male and female rats is low, there is a high expression of insulin when compared with the BR-1 group.

The existence of a positive influence with the treatment of rice analogue for 14 days on glucose levels, serum insulin levels and insulin expression can be estimated because of the components contained in rice analogue such as resistant starch and fibre contained in mocaf, corn and seaweed which causes low GI so that it helps in regulating blood glucose levels, as well as the presence of more antioxidant content which plays a role in reducing oxidative stress that occurs in DM type 2 (Uchegbu and Ishiwu, 2015). Reduced oxidative stress in DM rats caused an improvement in $\beta$ pancreas cells so that insulin secretion increased, which can be evidenced by the high intensity of insulin expression at IHC. Increased secretion of serum insulin causes a decrease in blood glucose levels in DM rats (Newsholme et al., 2014).

\section{Conclusion}

This study concluded that rice analogue consisting of mocaf, corn, pigeon pea and seaweed has a low GI and the rice analogue can increase serum insulin, improve morphological Langerhans and insulin expression in rats model of type $2 \mathrm{DM}$. We suggest that further histological testings are needed to know the number of pancreatic cells quantitatively.

\section{Conflict of interest}

The authors declare no conflict of interest.

\section{Acknowledgments}

The authors are indebted to the Community Resilience and Economic Development (CaRED) Programme, a Research Collaboration between Universitas Gadjah Mada and the New Zealand Government for financial support of the study. Thank you to Dr Janed Reid, Massey University, New Zealand for proofreading this article.

\section{References}

Anwar, K., Wigati, D., Sudarsono and Nugroho, A.E. (2017). Blood glucose reduction of combination of Andrographis paniculata (Burm.f) Ness and Morinda citrifolia L. ethanolic extract in neonatal streptozotocin-induced Type 2 diabetes mellitus rats.
International Food Research Journal, 24(5), 21532160.

Asarian, L. and Geary, N. (2013). Sex differences in the physiology of eating. American Journal of Physiology - Regulatory, Integrative and Comparative Physiology, 305(11), R1215-R1267. https://doi.org/10.1152/ajpregu.00446.2012

Budijanto, S., Sadek, N.F., Yuliana, N.D., Prangdimurt, E, and Priyosoeryanto, B.P. (2016). Potensi Beras Analog sebagai Alternatif Makanan Pokok untuk Mencegah Penyakit. Jurnal Pangan, 25(1), 61-70. [In Bahasa Indonesia].

Budijanto, S. and Yuliana, N.D. (2015). Development of Rice Analog as a Food Diversification Vehicle in Indonesia. Journal of Developments in Sustainable Agriculture, 10, 7-14.

Firdausia, R.S. (2018). Pengaruh Diet Beras Analog Berbahan Baku Mocaf, Jagung, Lebui Dan Rumput Laut Pada Tikus Model Diabetes Mellitus Tipe 2. Yogyakarta: Universitas Gadjah Mada. Thesis. [In Bahasa Indonesia].

Franciska, C.Y., Tamrin, S. W. and Warji. (2015). Pembuatan dan Uji Karakteristik Fisik Beras Analog dengan Bahan Baku Tepung Cassava yang Diperkaya dengan Protein Ikan Tuna. Indonesia: Fakultas Pertanian, Universitas Lampung, MSc. Thesis. [In Bahasa Indonesia].

Hu, F.B., Van Dam, R.M. and Liu, S. (2001). Diet and risk of type II diabetes: The Role of Types of Fat and Carbohydrate. Diabetologia, 44(7), 805-817. https:// doi.org/10.1007/s001250100547

Julia M.W., David J.A. and Jenkin. (2007). Carbohydrate Digestibility and Metabolic Effects, The Journal of Nutrition, 137(11), 2539S-2546S. https:// doi.org/10.1093/jn/137.11.2539S

Le May, C., Chu, K., Hu, M., Ortega, C.S., Simpson, E.R. and Korach, K.S. (2006). Estrogens protect pancreatic $\beta$-cells from apoptosis and prevent insulin -deficient diabetes mellitus in mice. Proceedings of the National Academy of Sciences, 103(24), 92329237. https://doi.org/10.1073/pnas.0602956103

Meyerholz, D.K. and Beck, A.P. (2018). Principles and approaches for reproducible scoring of tissue stains in research. Springer Nature, 98, 844-855. https:// doi.org/10.1038/s41374-018-0057-0

Newsholme, P., Cruzat, V., Arfuso, F. and Keane, K. (2014). Nutrient regulation of insulin secretion and action. Journal of Endocrinology, 221(3), R105R120. https://doi.org/10.1530/JOE-13-0616

Nugroho, A.E., Rais, I.R., Setiawan, I., Pratiwi, P.Y., Hadibarata, T., Tegar, M. and Pramono S. (2014). Pancreatic Effect of Andrographolide isolate from 
Andrographis paniculata. Pakistan Journal Biological Sciences, 17(1), 22-31. https:// doi.org/10.3923/pjbs.2014.22.31

Noviasari, S., Kusnandar, F., Setiyono, A. and Budijanto, S. (2015). Beras analog sebagai pangan fungsional dengan indeks glikemik rendah. Jurnal Gizi dan Pangan, 10(3), 225-232. [In Bahasa Indonesia].

Rani, S., Poswal, G., Yadav, R. and Deen, M.K. (2019). Screening of Pigeon, pea (Cajanus cajan L.) Seeds for Study of their Flavonoids, Total Phenolic Content and Antioxidant Properties. International Journal of Pharmaceutical Sciences Review and Research, 28(2), 90-94.

Sadek, N.F. (2017). Studi Penghambatan Karsinogenesis Kolon Oleh Beras Analog Yang Diperkaya Ester Fitosterol. Bogor: Institut Pertanian Bogor. Thesis. [In Bahasa Indonesia].

Saeedi, P., Petersohn, I., Paraskevi, S. and Belma, M. (2019). Global and regional diabetes prevalence estimates for 2019 and projections for 2030 and 2045: Results from the International Diabetes Federation Diabetes Atlas $9^{\text {th }}$ edition. Diabetes Research and Clinical Practice, 157, 107843. https:// doi.org/10.1016/j.diabres.2019.107843

Sani, P.N. (2018). Efek Diet Beras Analog Fungsional (Formula 30 dan F31) yang Berbasis Jagung, Mocaf, Kacang Lebui dan Rumput Laut terhadap Tekanan Darah Tikus Hipertensi Terinduksi Deksametason. Yogyakarta: Universitas Gadjah Mada. Thesis. [In Bahasa Indonesia].

Sari, I.P., Lukitaningsih, E., Rumiyati, R. and Setiawan, I.M. (2013). Glycaemic Index of Uwi, Gadung, and Talas Which Were Given on Rat. Majalah Obat Tradisional (Traditional Medicine Journal), 18(3), 127-131.

Sekhon, J., Grewal, S. K., Singh, I. and Kaur, J. (2017). Evaluation of nutritional quality and antioxidant potential of pigeon pea genotypes. Journal of Food Science and Technology, 54(11), 3598-3611. https:// doi.org/10.1007/s13197-017-2818-y

Srikaeo, K. and Sangkhiaw, J. (2014). Effects of amylose and resistant starch on glycaemic index of rice noodles. LWT - Food Science and Technology, 59 (2), 1129-1135. https://doi.org/10.1016/ j.lwt.2014.06.012

Steyn, N., Mann, J., Bennett, P., Temple, N., Zimmet, P. and Tuomilehto, J. (2004). Diet, nutrition and the prevention of type 2 diabetes. Public Health Nutrition, 7(1A),147-65. https://doi.org/10.1079/ PHN2003586

Sumardiono, S., Pudjihastuti, I., Poerwoprajitno, A.R. and Suswadi, M.S. (2014). Physichocemical
Properties of Analog Rice from Composite Flour Cassava, green bean, hanjeli. World Applied Sciences Journal, 32(6), 1440-1146

Syamsul, E.S., Nugroho, A.E. and Pramono, S. (2011), The Antidiabetics of Combination of Metformin and Purified Extract of Andrographis paniculata in High Fructose-Fat Fed Rats, Majalah Obat Tradisional, 16(3), 124-131.

Uchegbu, N. and Ishiwu, C. (2015). Germinated Pigeon Pea (Cajanus cajan): a novel diet for lowering oxidative stress and hyperglycemia. Food Science and Nutrition, 4(5), 772-777. https:// doi.org/10.1002/fsn3.343

William, T. and Cefalu, M.D. (2017). Standards of Medical Care in Diabetes - 2017.The Journal of Clinical and Applied Research and Education, Diabetes care. Vol. 40, Supplement 1. USA: American Diabetes Association.

Witosari, N. and Widyastusi, N. (2014). Pengaruh Pemberian Jus Daun Ubi Jalar (Ipomoea batatas (L.) Lam) Terhadap Kadar Kolesterol Total Tikus Wistar Jantan (Rattus norvegicus) yang Diberi Pakan Tinggi Lemak., Journal of Nutrition College, 3(4), 638-646. https://doi.org/10.14710/jnc.v3i4.6863

Wuhan Fine Biotech. (2016). Rat Ins (Insulin) ELISA Kit Manual Instruction ER1113. Wuhan Fine Biological Technology. Retrieved on June 29, 2016. Website: https://www.fn-test.com/content/uploads/ product/manuals/elisa/ER1113.pdf

Yahya, N.S.W. (2013). Indeks glikemik beras analog berbahan baku menir dengan penambahan ekstrak teh hitam. Bogor: Institut Pertanian Bogor. Thesis. [In Bahasa Indonesia]. 